\title{
The Impact of Parents Attitudes on Their Children's Distance Learning during COVID-19 Outbreak
}

\section{Harisa Mardiana}

Universitas Buddhi Dharma

harisa.mardiana@ubd.ac.id

\section{Article History}

received 17/5/2021

\begin{abstract}
Due to the COVID-19 outbreak that spread throughout the world, many activities were carried out at home, especially learning conducted online. The purpose of this study was to describe the impact of parents' attitudes on children in online learning. This study used a qualitative method by conducting interviews with four seventh grades parents, three of seventh grades teachers as representatives of the school, and three of seventh grades students. The results obtained are that parents need guidance in teaching children, extraordinary patience. On the other sides, teachers as facilitators can provide collaborate with parents to educate students. In contrast, students can convey their opinions to teachers about how to learn with parents, and teachers can help parents and students in online learning. Hence, learning for the COVID-19 outbreak can run smoothly so that student education will not be left behind due to the COVID-19 outbreak
\end{abstract}

Keywords: Parents, teachers, students learning, online learning

\begin{abstract}
Abstrak
Sejak wabah COVID-19 yang menyebar ke seluruh dunia, banyak kegiatan yang dilakukan di rumah, terutama dalam pembelajaran yang dilakukan secara dalam jaringan (daring). Tujuan penelitian ini adalah mendeskripsikan pengaruh sikap orang tua terhadap anak dalam pembelajaran daring. Penelitian ini menggunakan metode kualitatif dengan melakukan wawancara dengan empat orang tua siswa kelas tujuh, tiga orang guru kelas tujuh sebagai perwakilan sekolah, dan tiga siswa kelas tujuh. Hasil yang diperoleh orang tua membutuhkan bimbingan dalam mendidik anak, kesabaran yang luar biasa. Di sisi lain, guru sebagai fasilitator dapat memberikan kerjasama dengan orang tua untuk mendidik siswa. Sebaliknya, siswa dapat menyampaikan pendapatnya kepada guru tentang cara belajar dengan orang tua, dan guru dapat membantu orang tua dan siswa dalam pembelajaran online. Dengan demikian, pembelajaran untuk wabah COVID-19 dapat berjalan dengan lancar sehingga pendidikan siswa tidak tertinggal akibat wabah COVID-19
\end{abstract}

Kata Kunci: Orang tua, guru, pembelajaran siswa, pembelajaran online 


\section{INTRODUCTION}

Early in 2020, the world was shocked by the deadly COVID-19 outbreak. People in the world must avoid this virus by staying at home, wearing a mask, and frequently washing their hands. Coronavirus makes all activities around the globe stagnate (UNESCO, 2020). In education, all activities at school and campus stop and learning activities carried out at home via the Internet. This learning disruption makes students shocked and terrified. But by providing accurate information from the Indonesian government, WHO, and UNESCO, student and teacher learning can run again even though there is no face-to-face meeting (UNESCO, 2020); (WHO, 2020); Direct parental involvement and its impact on online learning in the COVID-19 outbreak is giving new signs in student learning. It can address the gap by exploring the factors that motivate parents of different socioeconomic status and educational levels to be involved in their children's education in Indonesia (Yulianti, Denessen, \& Droop, 2019).

Nevertheless, many parents feel overwhelmed in accompanying their children to online learning. There are even children who are on strike because their parents treat them harshly. Other parents feel overwhelmed because they do not think that their child's learning requires deep thinking, even though all the teaching is in printed books (Republika \& Saubani, 2020). Another problem is parents who neglect themselves not to be involved in their child's education to leave for the teacher or child caregiver to take care of. Besides, some parents do not know anything about school because their school level is low; parents like this always ask teachers or people who understand better about education (Antara News.com \& Katriana, 2020).

Moreover, the parents who work with school-age children and face the challenge of ensuring that their children are in a safe learning environment while working. A more severe and frightening challenge for low-income families, these families have more problems learning online (Bender \& UNICEF, 2020). The big challenge is that the outbreak has seriously limited the before and after-school programs and arrangements to look after their children.

According to Reimers, et al., (2020), parents' role in the family is vital in children's development and education. It is not only about teaching children to be able to do something or think about something, but also to educate children to become more mature individuals. Other researchers Bender \& UNICEF (2020) revealed that parental control for studying, playing, and other activities must be improved because the development of academic or emotional abilities has its characteristic values. The researcher Ciarrusta \& Alejandro (2020) indicated that parents should monitor children's expertise, knowledge, and skills and accompanying emotional development. It is related to the education provided by teachers and schools so that every step of the child's growth and monitoring the outcome.

On the other hand, some parents do not think that they must take an active role or do not feel involve and develop personal self-efficacy beliefs that they are less effective in supporting children's learning at home and school. Hence, they need encouragement from teachers and schools (Feuerstein, 2001). Some parents have little influence on children's learning lives at school and teachers and leave them entirely up to school and teachers. Parents argue that schools and teachers provide education. The lack of parental involvement in children's education makes the relationship between children and parents stretched and not involved in children's spiritual, emotional, and cognitive development. This kind of relationship leaves children unprotected if they have problems (Baker \& Manfredi-Petitt, 2004).

Researchers Berthelsen \& Walker (2008) found that parents' and teachers' involvement and cooperation in children's educational development had higher levels of pro-social behavior and academic achievement. According to Patrikakou (2015), the school's role in determining parents' and teachers' involvement in communicating about 
their children studying at the school makes the relationship between the school, teacher, and parents a constructive correlation in the child's educational journey. Also, Swick (1992) informed that establishing a good relationship between parents, school, and teachers at the beginning of the school year is essential, especially for parents with children entering elementary school.

Contrary to the researchers above, Dhawan (2020) informed that in the COVID19 pandemic, parents are overwhelmed by their children's tasks so that parents cannot do other activities and neglect household chores. Research from UCLG, Metropolis \& UN-Habitat (2020) confirmed that if it found that children are playing games but do not learn to make parents lose patience and often become violent. Loud protests from parents felt the burden of assignments given by teachers online was too much and substantial. Not a few parents think burdened and even get sick and go to the hospital (Horowitz \& Igielnik, 2020).

Some parents mention that online learning is unclear, because students cannot be controlled during their learning. On the other sides the teachers depend on parents in student education and learning. Moreover, many parents complain about online learning because of limitations in learning materials and difficulties in using digital technology. However, in this lesson there is a forum that parents, students and teachers can use to discuss student learning (Ciarrusta \& Alejandro, 2020). Hence, the teachers expect parents to be their partners in helping their children learn. Partnering includes participating in homework and staying in touch with the school. Nevertheless, the teacher criticized the parents for lacking support, even though they acknowledged that the family was struggling to make ends (KEMENDIKBUD, 2020).

By referring to researchers who agree with the parents' participation and who contradict the parents' involvement, this study concludes that parents must accompany their children in any condition, either parents' and the emotional development, mental, spiritual, cognitive abilities, skills and knowledge development. And the research aims to investigate parents' engagement for children's online learning and to watch the child. This research seeks online education related to teachers and schools in the COVID-19 pandemic. Also, to seek the children's online learning solution and involving parents in children's development during the COVID-19 outbreak (Bender \& UNICEF, 2020)

On the other hand, some parents do not think that they must take an active role or do not feel involve and develop personal self-efficacy beliefs that they are less effective in supporting children's learning at home and school. Hence, they need encouragement from teachers and schools (Feuerstein, 2001). Some parents have little influence on children's learning lives at school and teachers and leave them entirely up to school and teachers. Parents argue that schools and teachers provide education. The lack of parental involvement in children's education makes the relationship between children and parents stretched and not involved in children's spiritual, emotional, and cognitive development. This kind of relationship leaves children unprotected if they have problems (Baker \& Manfredi-Petitt, 2004).

Effective parenting practices for their children provide realistic expectations for children's behavior, such as helping parents. The factor of access to information about children and support for healthy children's resilience make children confident. Practical parenting skills include talking and reading books to children, playing with children, providing materials that stimulate and enrich children's vocabulary, and setting clear and consistent boundaries (Brossardi, et al., 2020). On the other hand, many parents give education and learning to children so that positive or negative interactions and discipline or undisciplined behavior reflects in the child's soul (Berthelsen \& Walker, 2008).

The most significant disruption to the education system occurred in the COVID19 outbreak, which resulted in the closure of all schools and study rooms. It made parents panic about their children's education (UNESCO, 2020). During the COVID-19 
outbreak, many parents were not ready for their children's learning due to online learning by using Internet technology. And not many parents are familiar with the technology. The unpreparedness of all education lines is a big obstacle, especially the change in learning and teaching from face to face to online learning. The government acknowledged this sudden readiness because of the outbreak (Republika \& Saubani, 2020). All education lines starting from the government, schools, campuses, principals, parents, teachers, and students, continually improve the online learning system so that young people continue to gain knowledge and continue to learn (KEMENDIKBUD., 2018).

Due to the COVID-19 outbreak forces closure of schools and universities, several students study at home so that students can continue to learn to use Internet technology as a viable alternative for now. This dangerous condition cannot deny to make everyone healthy and avoid the Coronavirus. Therefore, the use of Internet technology is a must and must be studied by all parties, including parents, students, teachers, and schools or universities (Li, C., \& Lalani, 2020).

\section{METHODOLOGY}

This study uses a qualitative approach design to explore respondents' perspectives on the topics discussed. The application of case study research investigates certain situations or events in detail through cases or case comparisons (Stake, 1994).

The purpose of using case studies is not to build old theories for certain phenomena, but to study a phenomenon or event in detail.

The number of respondents in this study was ten respondents consisting of four parents of seven grades students, three teachers of seven grades students, and three of seven grades students. Due to the COVID-19 outbreak, the interview and FDG conduct through WhatsApp. The interview uses semi-structured interviews, and in the FDG, researchers interviewed teachers on the one hand and parents, on the other hand, in different places. In the interview, researchers used Google Classroom chat learning media, and students were asked one by one and answered in privacy to the researcher. And all of the respondents have devices either using android or laptop with internet data on it.

There are 20 questions, but each of the respondents does not have the same issues. The questions for parents asked the teachers or the students. Some of the respondents may have only eight questions, and some may have15 or more items.

\section{RESULT AND DISCUSSION}

\section{RESULT}

The results of interviews given to parents, teachers, and students explained that learning is significant even in pandemic or outbreak conditions. Education must continue to continue to carry on the nation's hopes.

In the interview with parents it showed that parents showed deep concern over their children's education. In educating children, parents must pay attention to several things, such as controlling learning time and how children learn to get homework from school and behave and socialize with those around them. Moreover, learning during the COVID-19 outbreak used the online learning method, and parents must participate in children's learning.

\section{Interviewing the parents:}

In an interview with the parents of seventh grade students, the researcher gave several interview results. 


\section{Parents 1.}

"Some parents who accompany or teach children to study at home complain and begin to be restless because they feel that the teacher's task is too much and heavy. Parents complain that their children's schoolwork is quite heavy; on the other hand, parents have to carry out household roles and simultaneously teach children to learn online."

According to Republika, \& Saubani (2020) parents are accustomed to being "spoiled" by circumstances where teachers do the learning to the students, and parents only receive results. Pandemic conditions force parents to participate in education, but not all parents can carry out this role. And finally, it causes chaos. Researcher (Bouthillier, 2002) revealed that learning systems like this are rooted in parents' minds, so switching to online learning systems is a disaster for parents. Even though the education systems interrelate between education at home and teaching at school, parents do not realize it. Besides, parents must be able to develop children's potential and recognize their strengths and weaknesses so that their interests can help them design the child's life.

\section{Parents 2.}

"In other cases, parents often impose their will on their children regardless of their thoughts and conscience. Parents feel they know best what is best for their children. It is often done by parents trying to make their dreams come true, which they could not achieve when they were young, through their children."

This incident should not happen if parents realize their children's potential and talents and provide moral support and means to help their children develop their potential and existing abilities(Reimers, F., Schleicher, A., Saavedra, J., \& Tuominen, 2020).

Parents must avoid mistakes in educating their children so that they grow fear, children become arrogant, and children are too comfortable who do not have the demands of life and love children so that children do not seek love outside the home. (Antara News.com, 2020). For these reasons, this is parents' obligation to continuously pursue knowledge, especially those related to children's education, to avoid mistakes in educating children that have harmful consequences for their future. Parents must pay more attention to their children, see the potential and talents in their children, and provide facilities and infrastructure to support their learning process. Parents' expectations will do everything to create a generation with noble morals and extraordinary insight and an unyielding spirit (Bender , L., 2020).

\section{Parents 3.}

"Another case, parents neglect themselves not to help their children study at home to have difficulty learning. And parents don't feel the need to help children learn, because the teacher has to teach the children".

According to Clinton, J., \& Hattie, (2013) parental involvement in education is not only for learning but also for shaping children's character. Parents ensure themselves to play an active role and have exceptional communication with children to 
have a healthy relationship between child and parent. There is a process of encouraging, accompanying, leading, and inspiring children. The research from UNICEF (2020) indicated that conceptually, parental involvement in the COVID-19 outbreak situation could be directly involved in their child's education, commit themselves and engage by schools and teachers in the child's learning process. Researcher Li \& Lalani (2020) informed that parents fulfill their duties in realizing the exact learning process. Parents play and communicate with children so that the learning process and children's character formation occur.

\section{Parents 4.}

"Many parents do not like children studying at home, because children feel at home when they are playing or resting, even in a pandemic situation. You can see parenting patterns when children study at home, let alone studying online, and parents have difficulty educating and assisting their children in learning."

Given the importance of parents' role in educating children, several studies have proven that parents have a significant share in supporting children's abilities who have a considerable percentage. One researcher from WHO (2020) showed that parents' role in determining children's learning achievement is vast. Suppose parents ignore their child's education, likely. In that case, the child will not succeed in learning. On the other hand, parents who always pay attention to their children's learning activities will be enthusiastic in education because the child knows if the parents support it.

During the COVID-19 outbreak, teachers and students in the education unit still had to carry out learning. According to the Ministry of Education and Culture (2020), the green zone can carry out a face-to-face learning process combined with technological aids in online learning. The teacher continues to function as the primary key in knowledge and improves the quality and competence of creating a productive learning atmosphere. The purpose of using technology tools is to familiarize teachers and students with online learning.

Interviewing with teachers showed great enthusiasm for using instructional technology. They try to make learning run well and without complaints from students. Indeed, some teachers have difficulty teaching online, but other teachers who have the ability and skills to help and explain how to use learning technology.

\section{Teacher 1.}

"Teachers recognize that face-to-face learning is significant so that teachers can assess and help character development and social interaction in children when conditions allow for face to face again."

Meanwhile, in the situation of the COVID-19 outbreak, people must avoid the susceptibility of Coronavirus, teachers and students to conduct lessons at home using Internet technology. Hence, teachers and students must be able to adopt Internet technology to achieve maximum learning. Letter on Web KEMENDIKBUD (2020) explained that distance learning is not moving face-to-face learning using Internet technology, but how to learn and provide knowledge is different. 


\section{Teacher 2.}

"On the other hand, some teachers find it difficult to adapt and adopt Internet technology. This difficulty made some teachers confused and frustrated that many lessons were put together and gave students a lot of work. The use of Internet technology is confusing for teachers".

Furthermore, technology's role in assisting and facilitating the teaching and learning process, distance, and time is no longer a barrier to teaching activities (Feuerstein, 2001). Therefore, several components in the teaching and learning process cannot replace by an online system, such as the formation of children's characters, social interactions, and building children's personalities. These three things are still prioritized and can collaborate with online learning systems, such as doing homework and online quizzes (Bender , L., 2020).

\section{Teacher 3.}

"The teacher tries to teach using the system provided by the school, even though sometimes there are many obstacles. However, students understand this difficulty because both teachers and students are still learning to use digital technology."

According to Collie \& Martin (2016) and Mardiana (2020), the teachers had taken advantage of online learning. They needed time to improve the learning process to adapt to technological changes that started with technology in the classroom and switched to virtual technology. It seems that the disruption of technology and innovating virtual technology have had a significant impact on teachers' abilities and skills. Other researchers Bank (2017) informed that the ability to adapt to Internet technology, teachers must have confidence and anticipate emotional intelligence.

Teachers must practice using Internet technology to make learning work well. Besides, teachers can also take advantage of features on the Internet designed for active self-perception and help students understand learning and increase students' knowledge, abilities, and skills (Desmal, 2017). Also, by using learning features, the behavior of teachers who were previously confused and frustrated using Internet technology can quickly adopt changes in technology, and changes in technological innovations can increase teacher knowledge, abilities, and skills (Savvidis, 2016).

Student perception. When interviewing the students towards online learning, most of the students declared that:

\section{Student 1.}

"Many students like online learning, which consider being more flexible in terms of time and less tense with teachers. Besides, if the teacher understands Internet technology, then the assignment given is not too much and does not burden students".

A survey of 1,045 students by the Indonesia University of Education - known by its Indonesian acronym UPI - found that $40.3 \%$ of student respondents were excellent with online learning. It can be flexible and financially efficient because students save money on transport fares or motorbike gasoline (Yamin, 2020). In online discussions, students respond to the subject matter (lectures from teachers, books, and others) and comment from one student to another. Students respond to learning topics in broader 
conversations, and most talk about individual problems and result in smaller interviews coinciding in the group (Smart , K. L., \& Cappel, 2006).

With long discussions sometimes hampered by many Internet data packages. Many students feel better blended learning to save data package.

\title{
Student 2.
}

"The most complicated thing in online learning is that it consumes a lot of data package to spend a lot of money on purchasing data packages per month. Also, many students do not have tools for learning, so they have to wait for their friends to finish studying".

The data package problem is so severe that the government, especially the Ministry of Education and Culture of the Republic of Indonesia, must issue rules and regulations. According to the Ministry of Education and Culture of the Republic of Indonesia (2020), a data package is provided for students and teachers so that online learning runs smoothly. The provision of the data package is taken from school operational assistance funds. And these funds are directly given to each school, and the school principal is entitled to issue these funds. (Yozami, 2020).

Other students' perception is parents. In the interview, the students showed the concern that their parents were involved in their study; parents also showed the worries and made them awkward.

\section{Student 3}

"The parents feel burdened if their children study online at home. Parents are too worried about their children whether they are serious about studying or not"

\section{Student 4.}

From the student in younger ages' perceptions.

\begin{abstract}
"Sometimes parents are impatient and accuse their children of only playing games, even though they are studying or making assignments. Children feel pressured by their parents' treatment, who do not help them but are even burdensome. So that learning becomes disrupted".
\end{abstract}

Another problem is the constraint with parents who are overwhelmed with online learning. Parents think that knowledge is at school and not at home. If their children learn online from home, parents feel depressed, especially if their children are still in elementary school, because children will ask their parents if they do not understand the learning (Berthelsen, D., \& Walker, 2008). Placing parents in online learning sees the responsibility of students in handling learning. Many students learn to relax and play so that parents feel anxious about this learning (Clinton, J., \& Hattie, 2013). Parents feel participating and involved in the education of their children. Therefore, parents have to discuss a lot with teachers and schools so that worries and worries can eliminate, and the children will learn peacefully (Hoover-Dempsey, K. V., Walker, J. M., Sandler, H. M., Whetsel, D., Green, C. L., Wilkins, A. S., \& Closson, 2005). 


\section{DISCUSSION}

In education, parents, teachers, and schools' involvement determines the character and success in the future for the children. Besides, society and the environment also dramatically learn the child's independence, self-confidence, and way of thinking (Brossard et al., 2020). Values and norms, and basic ethics of children must be strong in educating and teaching children. An example of a good relationship between parents, children, and teachers is to show how children ask open-ended questions. Teachers and parents should give the children necessary character skills such as manners, asking the right questions, and not painful in line with a character learning at home and school (Bouthillier, 2002); (Patrikakou, 2015).

According to Baker \& Manfredi-Petitt (2004), good relationships between parents and teachers lead to better children's learning and provide opportunities for children to better communicate with adults and peers. Furthermore, children can make logical decisions to determine the direction and journey through their actions and words, which constitute a large part of their life. Also, researcher Berthelsen \& Walker (2008) indicated that teachers could give examples of good ways to ask questions or communicate with others, such as asking questions in games and reading stories to children. Therefore, if the relationship between parents and teachers is good and gives an excellent example to the child, it will become the child's work habits, attitude, and academic achievement results.

Due to social skills in society, parents and teachers must develop and exemplify adapting to situations and relationships. Building effective parent-school partnerships can address gaps in opportunities for children with disabilities and difficulties in achieving academic results. Besides, the positive relationship proved between parents and teachers in improving academic achievement, social competence, and children's emotional well-being. When parents and teachers work together as partners, their presentations are better at school and at home (Cullingford, C., \& Morrison, 1999).

The biggest problem with the student-teacher relationship is the large number of children missing from class. Attendance is minimal, about ten days of skipping a month. It is worrying because it can result in children dropping out of school. In interviews with several teachers, it was difficult to contact parents and children, so the solution to the problem would take longer (Antara News.com, 2020). In online learning, teachers always encourage students. Hence, students' learning runs well (Bender , L., 2020). Some students mentioned that the relationship between children and parents was not harmonious; sometimes, they were abused or neglected by their parents (Brossard et al., 2020). Amid the disruption of the coronavirus outbreak, parents expressed concern about their child's falling behind in school, with three in ten saying they were deeply concerned. (Desforges, C., \& Abouchaar, 2003), parents whose children receive face-to-face and online instruction are likely to worry not only about getting serious teaching, but also lacking understanding for their children about the instructions given by the teacher (Yamin, 2020)

To overcome the problem, many teachers communicate with students personally, and the conversation results can be displayed to parents so that there is a solution to the problem. The researchers Adams, Haris, \& Suzet (2016) revealed that many teachers mentioned that students have difficulty trusting teachers because of past experiences with adults. In this problem, the teacher approaches students and assures students that the teacher will help students. So the teacher must show that the teacher is helping students and not ignoring or tricking them (ibid, p. 60-61). Besides, the teacher provides continuous motivation to students so that they can learn well. Moreover, the teacher motivates students in learning and even informs them the day before it starts to attend online on their learning schedule. If they are inspired and encouraged, many students are willing to continue learning, so online learning is not a 
problem. On the other hand, many students trust teachers more than their parents because teachers can understand students. And good communication between teachers and students will enhance student learning (Banks, 2017). Online learning using Internet technology requires a data package of Internet. Many students complain that they use too much data package of Internet. This problem is not only from students, but teachers also have the same issues. And this problem has been handled by the Ministry of Education and Culture, and the data package funds of the Internet are sent directly to schools through school operational assistance funds (KEMENDIKBUD, 2020); (Yozami, 2020).

A crucial problem for students is dealing with depressed parents and have deep worries about children's behavior. Parents think that their child is not serious about studying, even though they already understand the study schedule and choose a flexible time (Li, C., \& Lalani, 2020). Parents cannot understand learning like this, because they think their children are not disciplined and only playing the games. All of this creates problems in children's learning. Thus, the teacher must communicate with parents to explain student learning's schedule and flexibility (Brossard et al., 2020).

Children's online learning solutions are by involving parents influence children's development. Children feel cared for and generate confidence in themselves that parents support children and parents understand the weaknesses of children's learning to be motivated to learn seriously (Shereen, M. A., Khan, S., Kazmi, A., Bashir, N., \& Siddique, 2020). Some parents said that they helped their children learn in the beginning, assisted them in learning every day, and sometimes parents who were working took time off to help their children. However, over time children can learn independently and are still monitored by parents via video calls.

Good relationships between parents, schools, teachers, and students can solve students' learning problems. The essential thing in this relationship is the consistency of parents, schools, teachers, and students to encourage school learning and create homework routines, such as establishing a quiet time and place, providing learning materials that are appropriate to children's capacities, and providing healthy physical activities to contribute to student success (Pirchio , S., Tritrini , C., Passiatore, Y., \& Taeschner, 2013).

By collaborating between parents, schools, teachers, and students, they can understand the goals and expectations of learning so that there is no concern for parents in online learning during the COVID-19 outbreak (Adams, D., Harris , A., \& Suzet, 2016). Therefore, cooperation between parents, teachers, and students will understand the goals and expectations of learning. This collaboration can be in the form of collaboration involving parents, teachers, and children (Desforges \& Abouchaar, 2003). Parents can ask the teacher the progress or weaknesses of their children, and the teacher can provide input to parents for their children's progress. Parental and teacher guidance provides motivation and self-confidence for children to resolve online learning problems during the COVID-19 outbreak.

\section{CONCLUSION}

Online learning during the pandemic has made a big difference in primary, secondary, and higher education. The change happened suddenly and shocked the public. By using Internet technology, all students can still learn from home using Internet technology. Internet technology is new, and parents, schools, teachers, and students must adapt rapidly to Internet technology. Many find it difficult and have a lack of technology, causing anxiety.

Over time, technological difficulties and stuttering could overcome. But most crucial is how parents deal with these changes. Worries that are very deep and depressed make students confused about facing their parents. Teachers can provide understanding and 
communicate with parents, so they are not worried and depressed in online learning. Giving knowledge, abilities, and skills to parents, teachers, and students make learning easy and comfortable. As the key to this learning to run smoothly is to provide knowledge, skills, and abilities to parents, teachers, and students about Internet technology. Thus during the COVID-19 period, all students could study at home using Internet technology.

\section{REFERENCES}

Adams , D., Harris , A., \& Suzet, M. (2016). Teacher-Parent Collaboration for an Inclusive Classroom: Success for Every Child. Adams , D., Harris , A., \& Suzet, M., 4(3), 58-72.

Antara News.com, \& K. (2020, June 12). KPAl tekankan peran penting orang tua dalam pembelajaran jarak jauh. https://www.antaranews.com/berita/1548740/kpaitekankan-peran-penting-orang-tua-dalam-pembelajaran-jarak-jauh

Banks, K. L. (2017). Technological Changes in Education: How Teachers Can Adapt. Bright Hub Education. www.brighthubeducation.com/teaching-methodstips/106543-21st-century-technological-changes-in-education/

Bender , L., \& U. (2020). (2020). Key Messages and Actions for COVID-19 Prevention and Control in Schools. UNICEF.

Berthelsen , D., \& Walker, S. (2008). Parents' involvement in their children's education. Family Matters, 79, 34-41.

Bouthillier, F. . \& S. K. (2002). Understanding knowledge management and information management: the need for an empirical perspective. . Information Research, , $8(1), 1-39$.

Brossard, M., Cardoso, M., Kamei, A., Mishra, S., Mizunoya, S., \& Reuge, N. (2020). Parental Engagement in Children's Learning. 1-6. https://www.unicefirc.org/publications/pdf/IRB 2020-09 CL.pdf

Clinton, J., \& Hattie, J. (2013). New Zealand Students' perceptions of parental Involvement in Learning and Schooling. Asia Pacific Journal of Education, 33(3), 324-337.

Cullingford, C., \& Morrison, M. (1999). Relationships Between Parents and Schools: A case study. Education Review, 51(3), 253-262. https://doi.org/https://doi.org/10.1080/00131919997498

Desforges, C., \& Abouchaar, A. (2003). The Impact of Parental Involvement, Parental Support and Family Education on Pupil Achievements and Adjustment: $A$ Literature Review.

Desforges, C., \& Abouchaar, A. (2003). The Impact of Parental Involvement, Parental Support and Family Education on Pupil Achievements and Adjustment: A Literature Review with. Education, 30(8), 1-110. https://doi.org/10.1016/j.ctrv.2004.06.001

Desmal, A. J. (2017). The impact of using social media and internet on academic performance case study Bahrain Universities. EAl Endorsed Transactions on Scalable Information Systems, 4(13), 1-12. https://doi.org/10.4108/eai.28-62017.152748

Feuerstein, A. (2001). School Characteristics and Parent Involvement: Influences on Paricipation in children's Schools. Journal of Education Research, 94(1), 12-29.

Hoover-Dempsey, K. V., Walker, J. M., Sandler, H. M., Whetsel, D., Green, C. L., Wilkins, A. S., \& Closson, K. E. (2005). Why do Parents Become Involved? Research Findings and Implications. The Elementary School Journal, 106(2), $105-130$.

KEMENDIKBUD. (2018). Kemendikbud Kaji Penerapan Mata Pelajaran Pendidikan Moral Pancasila. 
KEMENDIKBUD, W. (2020). Bantu Guru Selenggarakan Pembelajaran Jarak Jauh, Kemendikbud Luncurkan Guru Berbagi. www.kemdikbud.go.id/main/blog/2020/03/bantu-guru-selenggarakanpembelajaran-jarak-jauh-kemendikbud-luncurkan-guru-berbagi

Li, C., \& Lalani, F. (2020). The COVID-19 pandemic has changed education forever. This is how. www.weforum.org/agenda/2020/04/coronavirus-education-globalcovid19-online-digital-learning/

Patrikakou, E. N. (2015). Relationships among Parents, Students, and Teachers: The Technology Wild Card. Procedia-Social and Behavioral Science, 174, 2253 2258. https://doi.org/10.1016/j.sbspro.2015.01.883

Pirchio , S., Tritrini , C., Passiatore, Y., \& Taeschner, T. (2013). The Role of the Relationship between Parents and Educators for Child Behaviour and Wellbeing. International Journal about Parents in Education, 7(2), 145-155. eslplus.eu/documents/The_role_of_the_Relationship_between_Parents_and_Edu cators_for_Child_Behaviour_and_Wellbeing.pdf

Reimers, F., Schleicher, A., Saavedra, J., \& Tuominen, S. (2020). Supporting the continuation of teaching and learning during the COVID-19 Pandemic - Annotated resources for online learning.

Savvidis, P. (2016). Top 6 benefits of using technology in the classroom. Webanywhere Stretch Beyond. www.webanywhere.co.uk/blog/2016/02/top-6benefits-technology-classroom/

Shereen, M. A., Khan, S., Kazmi, A., Bashir, N., \& Siddique, R. (2020). COVID-19 Infection: Origin, Transmission and Characteristics of Human Coronaviruses. Journal of Advanced Research, 24, 91-98. https://doi.org/https://doi.org/10.1016/j.jare.2020.03.005

Smart , K. L., \& Cappel, J. J. (2006). Students' Perceptions of Online Learning: A Comparative Study. Journal of Information Technology Education, 5, 201-219. https://doi.org/10.28945/243

Stake, R. E. (1994). Case studies. In \& Y. S. L. (Eds. . N. K. Denzin, Y. S. Lincoln, N. K. Denzin (Ed.), Handbook of Qualitative Research (p. . 236-247). SAGE.

UNESCO. (2020). UNESCO. (2020). Learning in the COVID-19 era. Education Series. Paris, France: UNESCO. Retrieved from https://en.unesco.org/news/learningcovid-19-era.

WHO. (2020). WHO. (2020). WHO Director-General's opening remarks at the media briefing on COVID-19 - 16 March 2020. Washington, DC: World Health Organization. Retrieved from https://www. who.int/dg/speeches/detail/who-directorgeneral-s-opening-remarks-at-the-media-bri.

Yamin, K. (2020). Mixed response but online classes to stay post COVID-19. University World News - The Global Window on Hlgher Education, Jakarta. www.universityworldnews.com/post.php?story=20200514121749886

Yozami, M. A. (2020). Permendikbud 8/2020 Direvisi, Dana BOS Bisa Buat Beli Pulsa Internet Guru dan Siswa. Jakarta: Hukum Online.Com. www.hukumonline.com/berita/baca/t5e9933296533d/permendikbud-8-2020direvisi--dana-bos-bisa-buat-beli-pulsa-internet-guru-dan-siswa/\#: :text=April 2020 Tanggapan-,Permendikbud 8\%2F2020 Direvisi\%2C Dana BOS Bisa Buat Beli,Pulsa 